\title{
With a Naturalist on Southampton Island
}

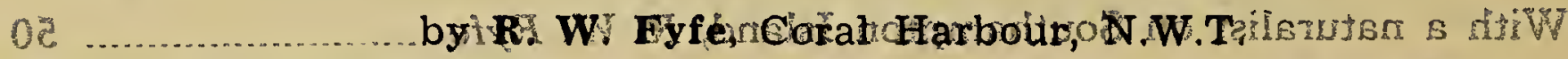

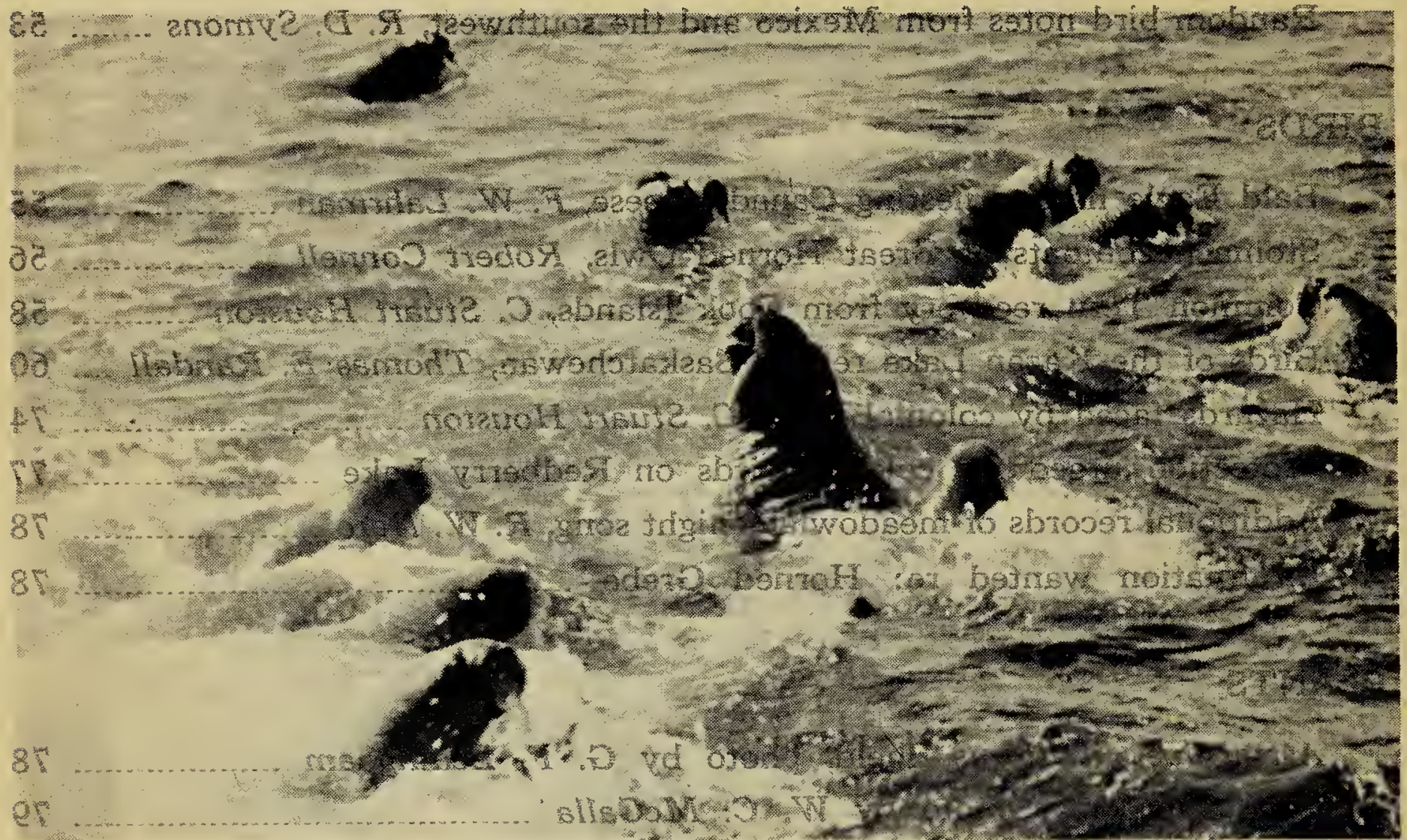

08

Walruses off Southampton lslond.

What is it like to live on Southampton Island? Can anything be worth-seeing - on -those-barrens?-Do you really like it up there?.oThese are some of the questions most frequently asked when we are in the south or in letters from our friends in the south. I think it is fair to say that most of those inquiring have not given the question much thought, or if they have, they consider the Aretic winters too forbidding to imagine themselves "living "'there." Actually, the two ... winters ... we have...spent ... in the north have been the most beautiful winters we have ever known.

obBecause. I.-have an - active--interest in natural history, I should like to tell something of the flora and fauna of Southampton Island so that readers may be able to appreciate in partiowhat the Aretic holds for the naturalist.

For many years this island has been ${ }^{5}$ well known to naturalists, primarily.... owing to thed irelative abundance of Arctic species of birds and mammals to be found here and in the adjacent watersoriof fot be 9720 species of birds considered to be Arctic species 66 are known to occur on the island and no less than 46 are known to nest here Most widely publicized are the extensive colonies of-Snow--and Blue Geese (roughly 10,000 birds nesting in each colony). These annually attract biologists to their breeding grounds to study the factors affecting the populations of these birds. Familiar winter birds in the south such as the Snow Bunting, Snowy Owl and Lapland Longspur are among the commonest nesting birds here. Indeed the snow Bunting is our first spring bird, arriving about the first of $\mathrm{A}$ April. In the settlement, the buntings remind one of the pugnacious House Sparrows in the south? as they âre continuousty around the buildings, nesting in any vacant crack and constantly quarreling amongst themselves. other common nesting birds include Whistling Swan Arctic Loon Sandhil Crane, Arotic Tern and all three species of the "graceful-marauding jaegers. The most abundant birdsfon the istand are the shorebirds. Founteen species

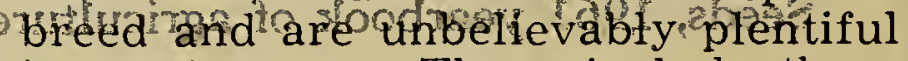
in most areas. These include three species of plover, Ruddy Turnstones

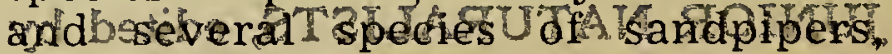
these latter being rather difficult to identify. The most impressive colony

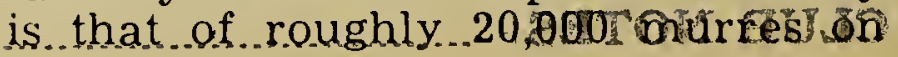




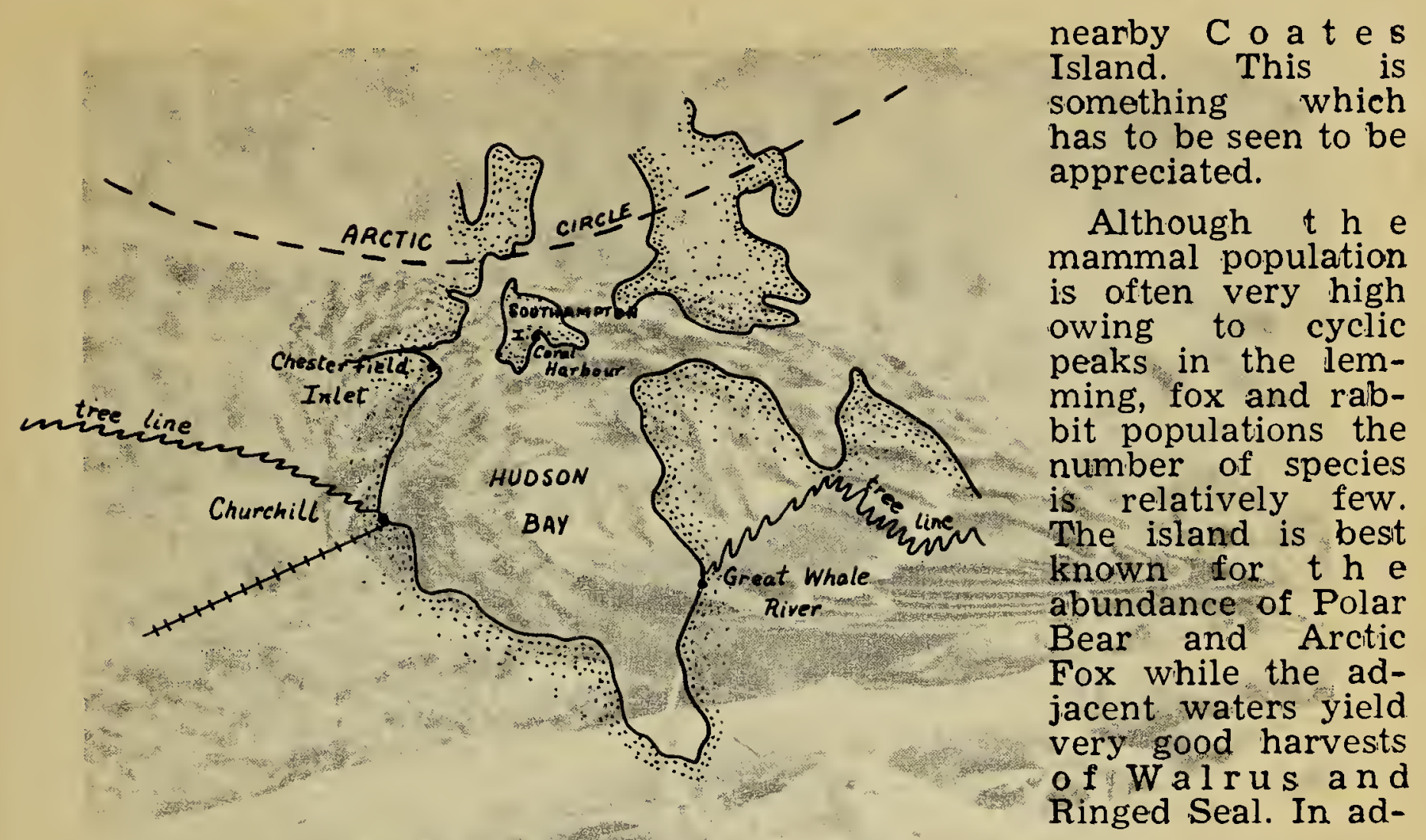

dition other species on the island include Red Fox and a weasel, w i $t h$ White Whale, Narwh a le, Harbour Seal, Bearded Seal and Harp Seal also found in the bays. There are no longer any Caribou on this is l a nd although Coates Island has a fairly large herd which is doing well. Most of the animals remain at some distance from the settlement although it is often possible to see seal and whales from our homes as they are only a few

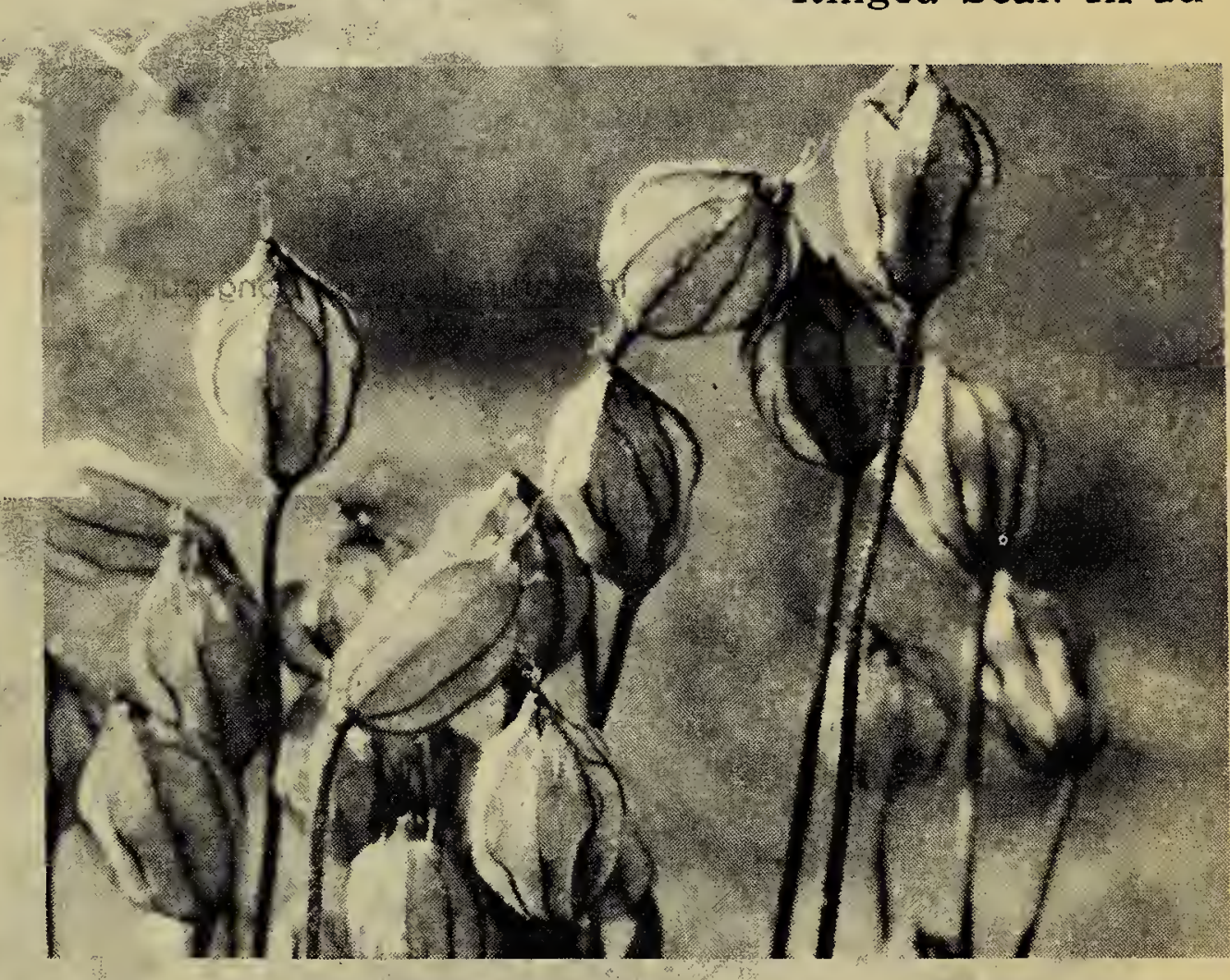

Melandrium sp., one of the northern lychnis. yards off shore. Also, in the winter the odd fox may enter the village and this year we had a Polar Bear in the village early in February.

The flona is typical of most Arctic islands and is quite impressive to anyone coming int the north for the first time. One is immediately impressed by the abundance of such species of cotton grass, white-flowered stellaria, and the daisy-like Matricaria. Any of these may literally carpet a given area during the brief growing season and some of the plants give a very good show of colour when in bloom.
To an outsider like myself this is all a world unto itself and at present I find myself not wanting to go south even for a few 'weeks' holiday, as there is still so much to see and learn about these so called "barren lands."

The following checklist has been made since my arrival in Coral Harbour on July 14, 1961, through to March 20, 1962:

Birds: Arctic Loon, Red-throated Loon, Whistling Swan, Canada Goose, Snow Goose, Blue Goose, Pintail, Oldsquaw, Common Eider, King Eider, Red-breasted Merganser, Rough-legged Hawk, Gyrfalcon, 
Vol. XX, No. 2

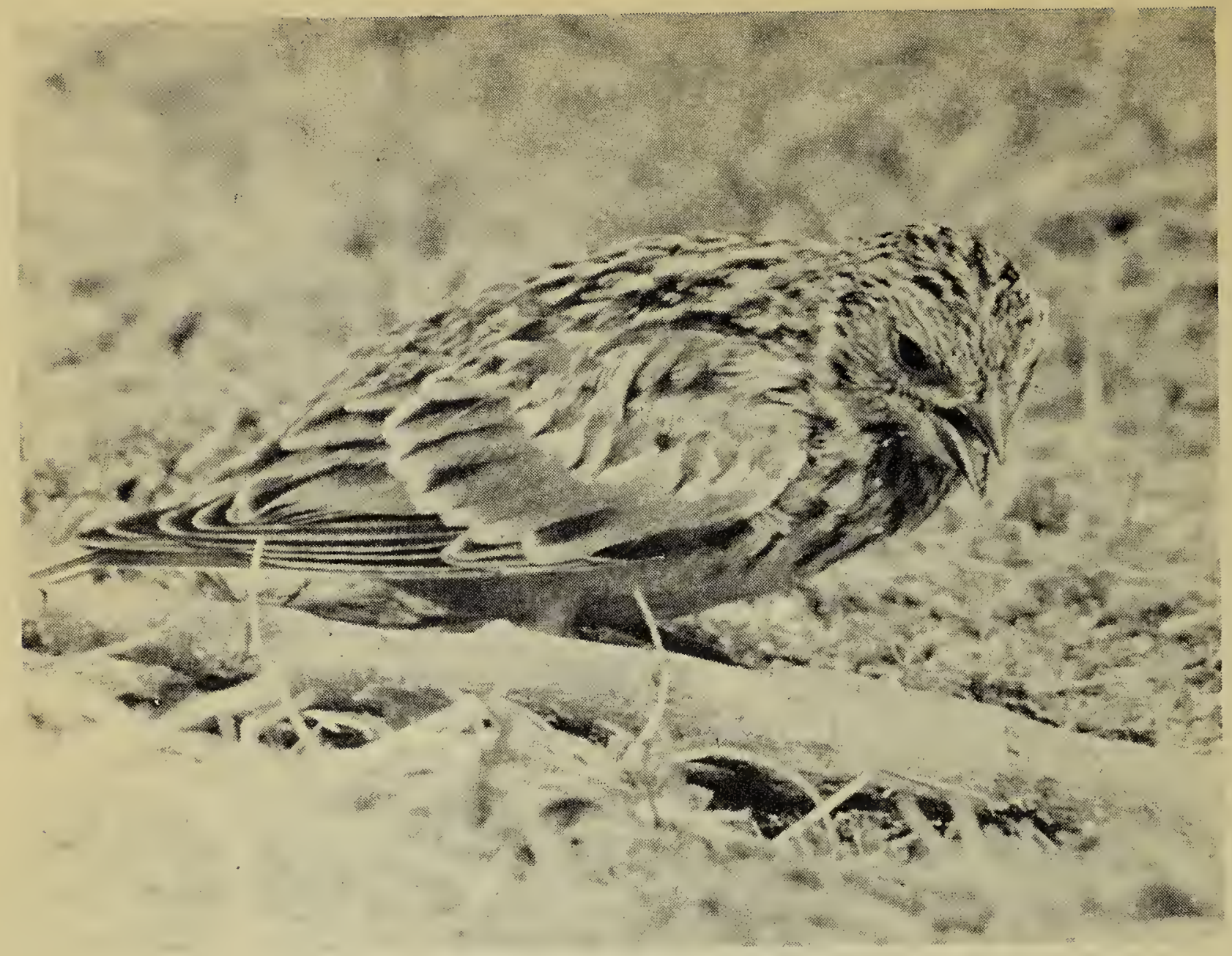

Immature Lapland Longspur.

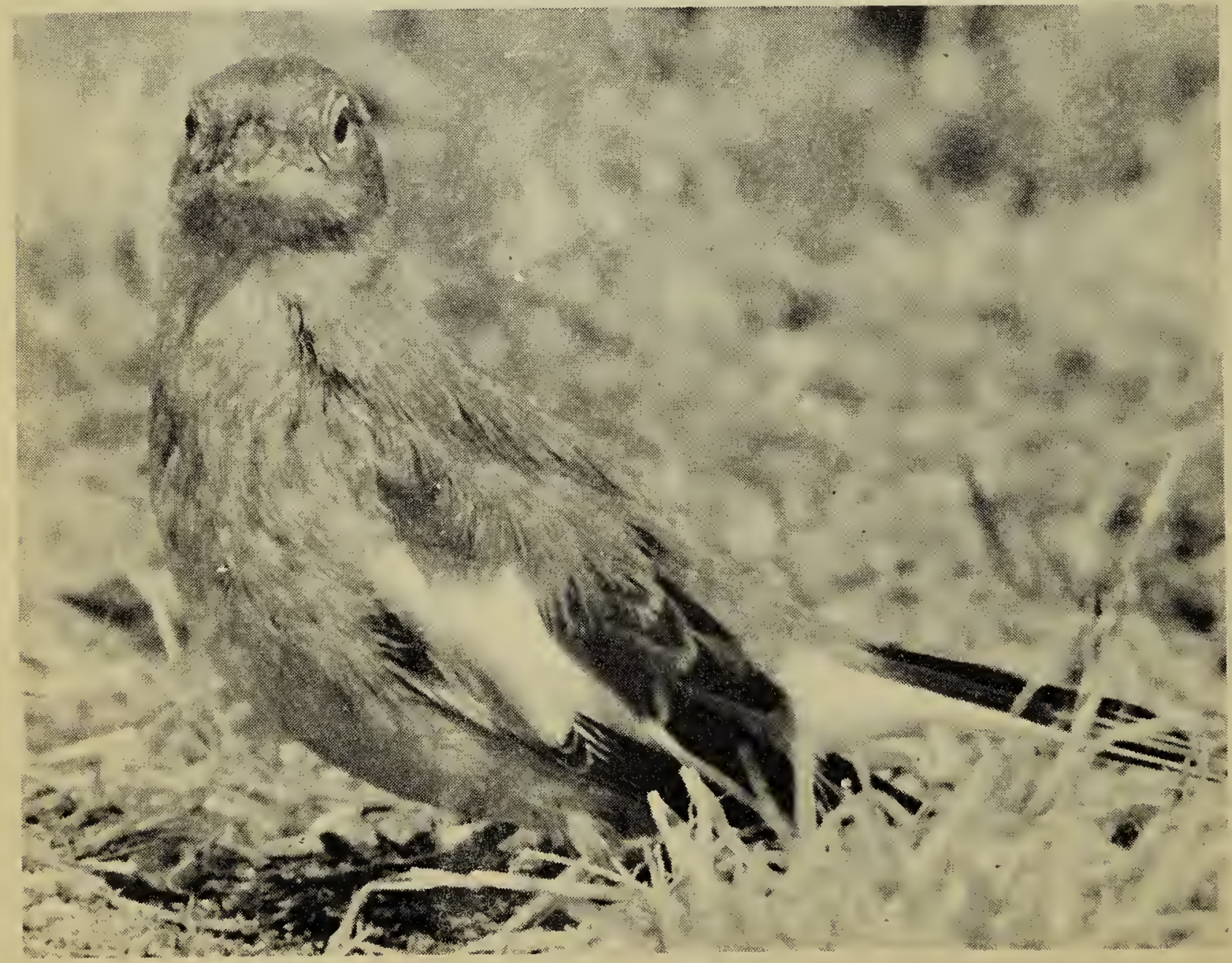

Immature Snow Buntina. 


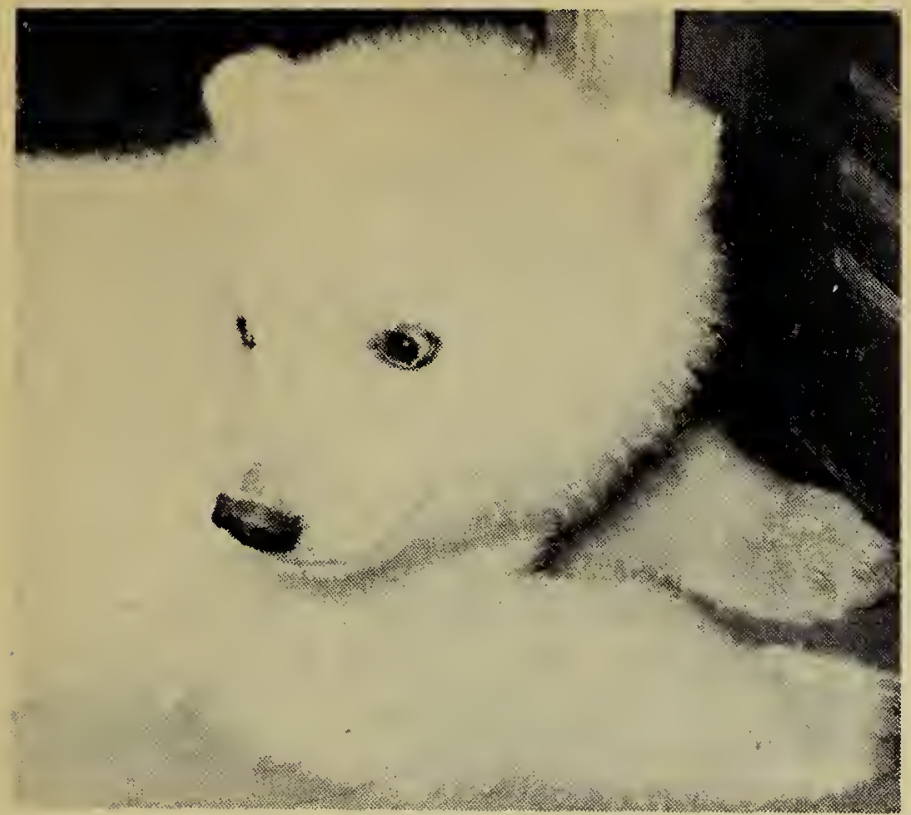

Polar Bear cub.

Peregrine Falcon, Willow Ptarmigan, Sandhill Crane, Ringed Plqver, American Golden Plover, Blackbellied Plover, Ruddy Turnstone, Purple Sandpiper, Baird's Sandpiper, Dunlin, Semipalmated Sandpiper, Red Phalarope, Pomarine Jaeger, Parasitic Jaeger, Long-tailed Jaeger, Glaucous Gull, Herring Gull, Sabine's Gull, Arctic Tern, Thick-billed Murre, Black Guillemot, Snowy Owl, Common Raven, Common Redpoll, Horned Lark, Water Pipit, Lapland Longspur, Snow Bunting.

Mammals: Lemming, Arctic Fox, Arctic Hare, Polar Bear, a weasel, Canibou, Walrus, White Whale, Ringed Seal, Harp Seal, Bearded Seal, Harbour Seal.

\title{
Random Bird Notes From Mexico and the Southwest
}

\author{
by R. D. Symons, Regina
}

Last winter I had the opportunity to follow some of our Saskatchewan birds south of the border on a trip that my wife and I took to Mexico. We left Regina on January 5 and travelled to Chihuahua, Mexico, by way of Lethbridge, and down the east side of the Continental Divide through Great Falls, Cheyenne, Denver, Santa Fe and El Paso.

Through Montana and Wyoming as far as Santa Fe, New Mexico, we encountered stormy weather and had little opportunity to see any birds except Harlequin Dúcks swimming happily about in the rushing waters on the Wind River canyon. At Chihuahua the weather was better, and for the six weeks we stayed there the sun shone continually. However, early January temperatures had been the coldest since the 1880 's, we were told, and almost all of the big palm trees were frozen so severely it was doubted they would survive.

We found that the city parks were good places to see birds, especially Bolivar Park which was right across from the house where we lived en pension. Flocks of grackles roosted in the big dry palm trees and made a lot of noise. The park is well lit and the activity seems to go on all night. These birds imitate the policeman's whistles in a most amusing way.

It is very difficult to get information about birds from Mexicans. They call anything with feathers "pajaritas"-little birds. The vaqueros know the Road Runner as "El paisano"- the Countryman. They know cranes, ravens and vultures, but not much else.

The state of Chihuahua is given over to ranching, and we were invited to stay with an American rancher at Rancho El Eden, 40 miles west of Chihuahua. Around the large springs here are clumps of very old alamos (cottonwoods). They make an oasis in the dry mesquite-dotted foothills and give the ranch its name. To the west the Sierra Madre towers stark and jagged and red. Side oats grama is the prevailing grass, and it was cured to bright Naples yellow. Shrikes are common here and are a regular feature of the landscape as they perch on the top of a prickly mesquite. Each bird sticks to its own territory, which would seem to be about seven or eight acres around its larder bush.

At Quintas Carolinas a group of scavanging Black Vultures looked for 